Table 1. Absorption of Antitoxoplasma Serum

\begin{tabular}{|c|c|c|c|}
\hline & Dye test & $\begin{array}{c}\text { Hæmagglut- } \\
\text { ination } \\
\text { test }\end{array}$ & $\begin{array}{l}\text { Complement- } \\
\text { fxation } \\
\text { test }\end{array}$ \\
\hline $\begin{array}{l}\text { Antitoxoplasma serum } \\
\text { unabsorbed }\end{array}$ & $\begin{array}{l}\text { Positive at } \\
1 / 1,280\end{array}$ & $\begin{array}{l}\text { Positive at } \\
1 / 1,280\end{array}$ & $\begin{array}{l}\text { Positive at } \\
1 / 640\end{array}$ \\
\hline $\begin{array}{l}\text { Antitoxoplasma serum } \\
\text { absorbed with toxo- } \\
\text { plasma suspension }\end{array}$ & $\begin{array}{l}\text { Positive at } \\
1 / 40\end{array}$ & $\begin{array}{l}\text { Negative at } \\
1 / 20\end{array}$ & $\begin{array}{l}\text { Negative at } \\
1 / 20\end{array}$ \\
\hline $\begin{array}{l}\text { Antitoxoplasma serum } \\
\text { absorbed with sensit- } \\
\text { ized human red cells }\end{array}$ & $\begin{array}{l}\text { Positive at } \\
1 / 1,280\end{array}$ & $\begin{array}{l}\text { Negative at } \\
1 / 20\end{array}$ & $\begin{array}{c}\text { Positive at } \\
1 / 1,280\end{array}$ \\
\hline $\begin{array}{l}\text { Antitoxoplasma serum } \\
\text { absorbed with unsen- } \\
\text { sitized human red cells }\end{array}$ & $\begin{array}{c}\text { Positive at } \\
1 / 1,280\end{array}$ & $\begin{array}{l}\text { Positive at } \\
1 / 1,280\end{array}$ & $\begin{array}{l}\text { Positive at } \\
1 / 1,280\end{array}$ \\
\hline $\begin{array}{l}\text { Normal human serum } \\
\text { control absorbed with }\end{array}$ & & & \\
\hline $\begin{array}{l}\text { toxoplasma suspen- } \\
\text { sion and then mixed } \\
\text { with antitoxoplasma }\end{array}$ & $\begin{array}{l}\text { Positive at } \\
1 / 640\end{array}$ & $\begin{array}{l}\text { Positive at } \\
1 / 320\end{array}$ & $\begin{array}{l}\text { Positive at } \\
1 / 640\end{array}$ \\
\hline $\begin{array}{l}\text { serum } \\
\text { Normal human serum } \\
\text { control absorbed with } \\
\text { sensitized human red } \\
\text { cells and then mixed } \\
\text { with antitoxoplasma } \\
\text { serum }\end{array}$ & $\begin{array}{l}\text { Positive at } \\
1 / 640\end{array}$ & $\begin{array}{l}\text { Positive at } \\
1 / 640\end{array}$ & $\begin{array}{l}\text { Positive at } \\
1 / 640\end{array}$ \\
\hline
\end{tabular}

as an absorbent was essentially the same as that with the mouse exudate antigen.

These experiments demonstrate that the antibody measured in the hæmagglutination test differs from that in either the dye or complement-fixation tests. Therefore the antigen or antigens responsible for the hæmagglutination test differ from those responsible for the dye and complement-fixation tests.

Public Health Laboratory,

D. G. FLECK

Cockett Road, Swansea.

${ }^{1}$ Siim, J. C., and Lind, K., Acta Path. Micro. Scand., 50, 445 (1960). ${ }^{2}$ Jacobs, L., and Lunde, M. N., J. Parasilol., 43, 308 (1957).

\section{Effect of a Magnetic Field on Sarcoma 37 Ascites Tumour Cells}

THIs communication deals with work on the effect of magnetic field on living ascites tumour cells in vitro. The hanging-drop culture was prepared by diluting a 7-day-old transplanted ascites mouse tumour with suitable aliquots of Tyrode solution. The culture slide to be exposed to the field was then placed between the poles of an Alnico permanent magnet in a horizontal position at a constant temperature of $37^{\circ} \mathrm{C}$. The field strength used during the experiment was about 4,000 gauss and was determined independently by the susceptibility technique. The control slides not exposed to the field were treated identically. The microscopic examination of the slides was carried out periodically.

The control tumour cells showed normal growth and active differentiation, even after $18 \mathrm{hr}$., whereas most tumour cells exposed to the field showed complete degeneration at the end of this period. These experiments were repeated several times with reproducible results. The slides made after $18 \mathrm{hr}$. were stained with acetocarmine and photomicrographs were made.

Although it is not possible to explain these results clearly at the present time, the following postulates and assumptions are considered in working out a hypothesis for this purpose. (1) The 'chemical components' in the cells have varying magnitudes of magnetic susceptibility representing the diamagnetic and the permanent and any transient paramagnetic contributions. Hence, the permanent and any transient components will experience varying forces under the influence of the magnetic field. (2) Although these forces are small from a macroscopic point of view, they may be enough to upset the delicate balance (chemical and other equilibria) inside and outside the cell. (3) Such changes are assumed, at least in part, to produce the degeneration of the colls.

We wish to thank Dr. G. S. Sperti for his encouragement and Messrs. Albert Gerth and Robert Neagele for their valuable assistance. Further work on the effect of a magnetic field on living cells will be published elsewhere.

Institutum Divi Thomæ, Cincinnati 6, Ohio.

Chemistry Department, University of Cincinnati, Cincinnati 21, Ohio.

\section{Indumati L. MULAY}

\section{N. MULAY}

\section{Association of Detectable Antibodies produced by $\mathrm{Haemonchus} \mathrm{spp.} \mathrm{Infections}$ in Cattle, with Serum Globulin Fractions}

EARLIER investigations have shown that cattle which exhibit a marked degree of natural resistance to infection with Haemonchus spp. also develop higher complement-fixation titres than susceptible cattle, and that rises in the complement-fixation antibody titres often occurred at the same time as rises in the gamma one fraction of the serum globulin. This resistance has been shown to be heritable ${ }^{1,2}$. These observations were made under field conditions where extraneous stimuli were likely to produce changes in the globulin fractions, so that the correlation between complement-fixation titres and the $\gamma$-l-globulin fraction was not always consistent and definite conclusions were not possible. To clarify this situation, cattle sera known to be positive by the complement-fixation test were fractionated and the fractions identified and tested for antibody content. The following is a brief account of the procedure and results obtained.

The $\beta$ - and $\gamma$-globulins were first separated from the serum by precipitation with 16 per cent sodium sulphate at $37^{\circ} \mathrm{C}$. The globulin was further fractionated on a diethylaminoethyl cellulose chromatographic column with gradient potassium acid phosphate buffer solutions ranging from $p \mathrm{H} 7 \cdot 0$, $0.005 M$ to $p H 5 \cdot 8,0 \cdot 1 M$, after the technique in refs. 3 and 4. Three antibody positive fractions were isolated in this manner. The protein content of these fractions was estimated by the biuret colorimetric $\operatorname{method}^{2,5}$. The relative concentration of the individual globulins in these fractions was ascertained by adding them to a known standard serum and observ. ing the alteration in the globulin fraction content of the serum by electrophoresis in an Antweiler microelectrophoresis apparatus. Complement-fixation test techniques were carried out as described in ref. 1, and hæmagglutination tests following the method in refs. 6 and 7 .

Considorable variation occurred in the relative amount of total protein in the samples, and antibody contents have therefore been expressed as antibody potency per gm. of protein. Complement-fixation test results have been expressed as 'index ratios' (refs. 2 and 8), which is the ratio of the amount of complement fixed by the serum in the presence of antigen to the amount fixed in the absence of antigen, after corrections, if necessary, have been made for anti-complementary effects of the antigen. Details of the results are shown in Table 1. 